Article

\title{
Synthesis of 2RS,4RS-1-[2-Phenyl-4-[2-(2-trifluromethoxy- phenoxy)-ethyl]-1,3-dioxolan-2-yl-methyl]-1H-1,2,4-triazole Derivatives as Potent Inhibitors of Brassinosteroid Biosynthesis
}

\author{
Kazuhiro Yamada, Yuko Yoshizawa and Keimei $\mathrm{Oh}$ * \\ Department of Biotechnology, Faculty of Bioresource Sciences, Akita Prefectural University, 241-438, \\ Shimoshinjo Nakano, Akita 010-0195, Japan
}

* Author to whom correspondence should be addressed; E-Mail: jmwang@akita-pu.ac.jp; Tel.: +81-18-872-1590; Fax: +81-18-872-1670.

Received: 21 February 2012; in revised form: 5 April 2012 / Accepted: 9 April 2012 /

Published: 13 April 2012

\begin{abstract}
Brassinosteroids are important phytohormones that affect many aspects of plant growth and development. In order to manipulate brassinosteroid levels in plant tissues by using specific biosynthesis inhibitors, we have carried out a systemic search for specific inhibitors of brassinosteroid biosynthesis. Synthesis of triazole derivatives based on the ketoconazole scaffold revealed a series of novel brassinosteroid biosynthesis inhibitors (the YCZ series). To explore the structure-activity relationships of this synthetic series, we now report the synthesis of new triazole derivatives with different aromatic structures at position 2 of 1,3-dioxolane skeleton. We found that the variation of aromatic substituent significantly affect the inhibitory potency. Structure-activity relationships studies indicated that 4-chlorophenyl analogue is the most potent inhibitor of BR biosynthesis with an $\mathrm{IC}_{50}$ value approximately $0.12 \pm 0.04 \mu \mathrm{M}$, while a bulky biphenyl group exhibited a great negative effect on promoting the inhibitory potency with an $\mathrm{IC}_{50}$ larger than $10 \mu \mathrm{M}$.
\end{abstract}

Keywords: brassinosteroid; brassinosteroid biosynthesis inhibitor; plant growth regulators

\section{Introduction}

Brassinosteroids (BRs), a class of polyhydroxysteroids widely distributed in plant kingdom, are potent phytohormones that affect many aspects of plant growth and development [1]. Physiological studies have demonstrated that BR can induce diverse cellular responses such as stem elongation, 
pollen tube growth, leaf bending, root inhibition, induction of ethylene biosynthesis and fruit ripening, and stress tolerance [1-3]. The identification of BR biosynthetic mutants of Arabidopsis, tomato, rice and pea established that BR is a new class of phytohormone with an essential role in plant growth and development [4-7]. Since then, efforts have been made to control the BR biosynthesis in plant tissues by genetic approaches and available evidence indicates that mutations in BR biosynthesis may be a means to improve biomass production [8,9]. Consequently, development novel methodology to manipulate BR levels in plant tissues attracts great research interests.

An alternative method to control the BR levels in plant tissues is the use of specific inhibitors that target the enzymes responsible for BR biosynthesis. BR biosynthesis inhibitors have consequently become highly viable candidates for plant growth regulators. Asami and Yoshida reported the discovery of brassinazole, the first synthetic BRs biosynthesis inhibitor (Brz series) [10]. Subsequent studies on the mode of actions of Brz provided important information about the functions of BRs [11,12]. Recent progress on molecular functional analysis enzymes of BR biosynthesis provided insight evidences that P450 enzymes play key roles in the process of hydroxylation of BR [13-15]. Accordingly, strategies for designing P450 inhibitors can be applied to the identification of BR synthesis inhibitors. Cytochrome P450 inhibition mechanisms have been studied in considerable detail [16], triazole derivatives have been demonstrated widespread utility as inhibitors of P450s, due to the intrinsic affinity of the nitrogen electron pair in heterocyclic molecules for the prosthetic heme iron [17].

Our research interests are in developing novel plant hormone biosynthesis inhibitors and the use of these compounds to explore the functions of plant hormones in plant growth and development [18-21]. In the previous work, we have shown that $2 R S, 4 R S-1$-[2-(4-chlorophenyl)-4-[2-(2-trifluoromethoxyphenoxy)-ethyl]-1,3-dioxolan-2-yl-methyl]-1H-1,2,4-triazole (YCZ-14, Figure 1) is a potent inhibitor of BR biosynthesis [22].

Figure 1. Chemical structure of YCZ-14 and general structure of the target compounds 7a-h.

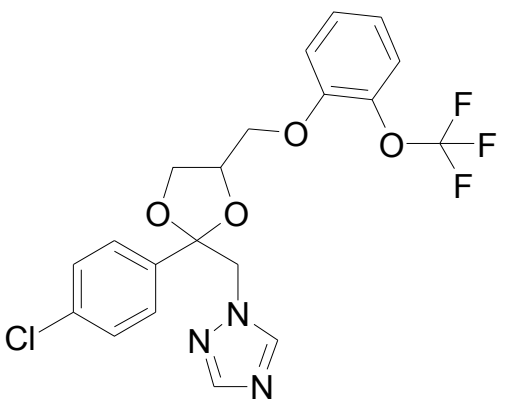

YCZ-14

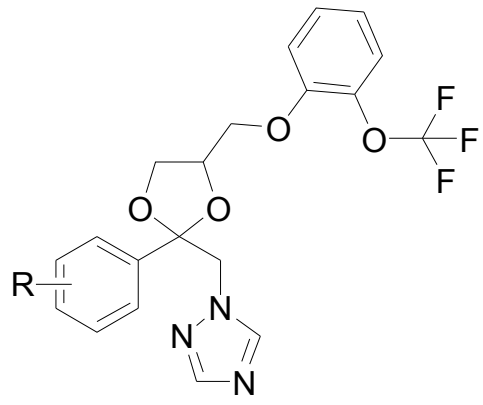

Target compounds $7 \mathbf{a}-\mathbf{h}$

The biological activity of this synthetic series (YCZ series) was evaluated by testing the ability of the compounds on retardation stem elongation of Arabidopsis seedlings. The compound-induced hypocotyls dwarfism were counteracted by the co-application of $10 \mathrm{nM}$ brassinolide, the most potent $\mathrm{BR}$, but not $1 \mu \mathrm{M} \mathrm{GA}_{3}$, which produced seedlings that resembled BR-deficient mutants. In order to further study the structure-activity relationships of $\mathbf{Y C Z}$ series, we report herein the synthesis of new triazole derivatives with different aromatic structure at the position 2 of the 1,3-dioxolane moiety to mimic the partial structure of 4-chlorophenyl moiety found in YCZ-14 (The general structure of 
target compounds $\mathbf{7 a}-\mathbf{h}$ is shown in Figure 1). Structure-activity relationships of newly synthesized compounds were discussed.

\section{Results and Discussion}

\subsection{Chemistry}

Target compounds $\mathbf{7 a}-\mathbf{h}$ were prepared according to a synthetic route (Scheme 1) as we previously described [22].

Scheme 1. The chemical synthesis of target compounds.

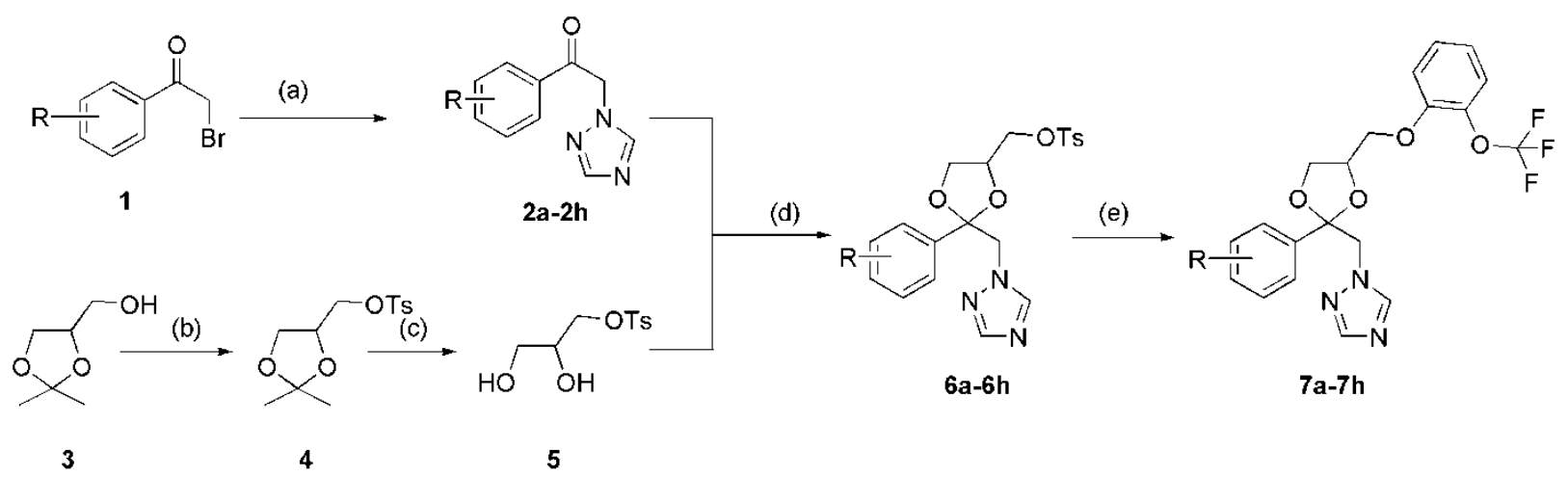

Reagents and conditions: (a) 1,2,4-triazole, triethylamine, DMF, $-10{ }^{\circ} \mathrm{C}, 1 \mathrm{~h}$, r.t., $3 \mathrm{~h}$; (b) $\mathrm{TsCl}$, pyridine, $0{ }^{\circ} \mathrm{C}$, acetone; (c) $\mathrm{HCl}$, Reflux, $6 \mathrm{~h}$; (d) 3 equiv. $\mathrm{TfOH}$, toluene, r.t., $60 \mathrm{~h}$; and (e) 2-trifluoromethoxyphenol, $\mathrm{KOH}, \mathrm{DMF}, 50{ }^{\circ} \mathrm{C}, 12 \mathrm{~h}$.

The key transformation of $\mathbf{2 a}-\mathbf{h}$ with compound $\mathbf{5}$ consisted of four steps: (1) formation of ethanones $\mathbf{2 a}-\mathbf{h}$; (2) tosylation of isopropylideneglycerol 3; (3) deprotection of isopropylidene ketal 4; and (4) ketal formation to generate $\mathbf{6 a}-\mathbf{h}$. Compounds $\mathbf{2 a}-\mathbf{h}$ were prepared by reacting different kinds of commercially available $a$-bromoketones 1 with triazole in DMF using a method that we described previously [23]. The alkylation of isopropylidene glycerol $\mathbf{3}$ was achieved using a method we described previously [22], and hydrolysis with $1 \mathrm{M} \mathrm{HCl}$ in $\mathrm{MeOH}$ yielded glyceryl tosylate 5. Ketal formation to generate $\mathbf{6 a}-\mathbf{h}$ were carried out using three equivalents of trifluoromethanesulfonic acid $(\mathrm{TfOH})$ in toluene at room temperature for $60 \mathrm{~h}$, according to a method previously described [22]. All of the compounds synthesized in this work consist of four stereoisomers, and they were subjected to biological studies without further purification.

\subsection{Bioassay Methods}

The bioassay used for determination the activity of BR biosynthesis inhibitors was carried out by a method as we described previously [22]. Arabidopsis BR synthesis-deficient mutants such as $d$ warf 1 show remarkable dwarfism and the opening of the apical hook of cotyledons in the dark [4]. This unique de-etiolation in the dark phenotype has been used for screening for BR biosynthesis inhibitors [24]. In the present study, we adapted this assay method to determine the effects of test compounds on hypocotyls elongation of Arabidopsis seedlings grown in the dark, and we co-applied BL and GA with 
the test compounds to determine the reversibility of their effects. With this assay system, we evaluated the biological activities of synthesized compounds.

\subsection{Biological Activities of Newly Synthesized Brassinosteroid Biosynthesis Inhibitors}

The chemical structures of compounds applied for biological studies are shown in Table 1. To identify the aromatic chemical structure at position 2 of 1,3-dioxolane ring responsible for the retardation of Arabidopsis stem elongation, various aromatic substituent were introduced to the inhibitors $\mathbf{7 a}-\mathbf{h}$.

Table 1. Inhibitory activity of triazole derivatives on Arabidopsis seedling growth.

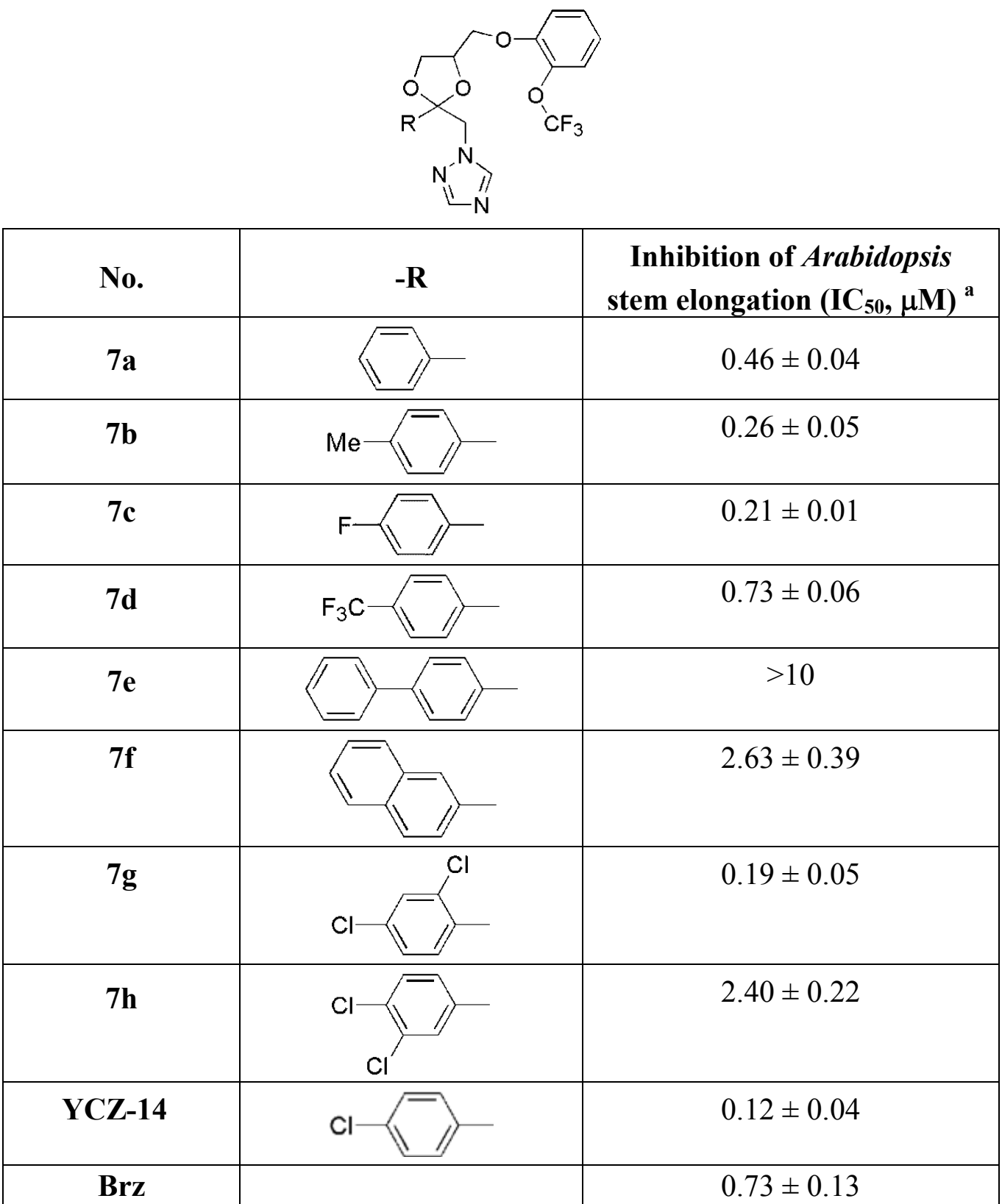

${ }^{a} \mathrm{The} \mathrm{IC}_{50}$ values of the test compounds for the inhibition of Arabidopsis stem elongation were calculated as described in experiment section. All of the experiments were performed at least in duplicate to establish the repeatability. 
We used YCZ-14 and Brz as positive controls. A phenyl analogue (compound 7a) was used as a baseline reference for structure-activity relationships discussions. The concentrations of all of the test compounds as well as Brz were assigned to be 0, 0.01, 0.05, 0.1, 0.5, 1 and $10 \mu \mathrm{M}$, and the $\mathrm{IC}_{50}$ values were calculated accordingly. As shown in Table 1, compound 7a exhibits inhibitory activity on retarding hypocotyls elongation of Arabidopsis seedling grown in the dark, with an $\mathrm{IC}_{50}$ value of $0.46 \pm 0.04 \mu \mathrm{M}$, while the $\mathrm{IC}_{50}$ of YCZ-14 was $0.12 \pm 0.04$ and Brz was $0.73 \pm 0.13 \mu \mathrm{M}$, respectively. This result indicates that the inhibitory potency of YCZ-14 (4-chlorophenyl analogue) is stronger than that of $7 \mathbf{a}$ and that a mono substituent at position 4 of the phenyl moiety may promote the inhibitory activity. To verify this possibility, we further introduce 4-methylphenyl, 4-fluorophenyl and 4-trifluoromethylphenyl moieties into the inhibitor (analogues 7b-d) to evaluate their effect on inhibitory activity.

We found that analogues with methyl and fluorine atom substituents at position 4 of the phenyl ring (compounds $\mathbf{7 b}, \mathbf{c}$ ) have a positive effect on promoting the inhibitory activity compared with that of $\mathbf{7 a}$, with $\mathrm{IC}_{50}$ values of $0.26 \pm 0.05$ and $0.21 \pm 0.01 \mu \mathrm{M}$, respectively. Interestingly, introducing a 4-trifluoromethylphenyl moiety (compound 7d) to the position 2 of 1,3-dioxolane, however, showed a significant negative effect on promoting inhibitory activity, with an $\mathrm{IC}_{50}$ value approximately $0.73 \pm 0.06 \mu \mathrm{M}$. It is worthwhile to note that compound $\mathbf{7 d}$ shares the common 4-trifluoromethylphenyl moiety with Brz220, the most potent inhibitor of BR biosynthesis inhibitor reported by Asami et al. (the Brz series) [25]. Data obtained in this work suggests that the structure requirements for these two synthetic series (Brz and YCZ) on inhibition of BR biosynthesis are different. This observation implies the binding site of $\mathbf{Y C Z}$ series may be different from Brz series. In order to further determine the structure-activity relationships of YCZ synthetic series, we next introduced a bulky aromatic moiety to the inhibitor. As shown in Table 1, the $\mathrm{IC}_{50}$ value of the biphenyl analogue 7e and naphthalene analogue 7f are greater than 10 and $2.63 \pm 0.39 \mu \mathrm{M}$, respectively. This result indicates that a bulky aromatic moiety significantly reduces the inhibitory activity. Although the variation of aromatic structure greatly affects the inhibitory activity of this synthetic series, the 4-chlorophenyl analogue (YCZ-14) is the most potent inhibitor. This observation suggests that the substituent(s) of chlorine atom on the phenyl moiety enhance the inhibitory activity of this synthetic series. Thus, we next synthesized 2,4-dichlorophenyl analogue $\mathbf{7 g}$ and 3,4-dichlorophenyl analog $\mathbf{7 h}$ for further structure-activity relationships studies. We found the $\mathrm{IC}_{50}$ values for $\mathbf{7 g}$ and $7 \mathbf{h}$ are $0.19 \pm 0.05$ and $2.40 \pm 0.22 \mu \mathrm{M}$, respectively. Although the structural difference of these two analogues is the position of the chlorine atom, the inhibition potencies of these two analogues are quite different. This result indicates that the position of the chlorine atom on the phenyl ring is sensitive to the binding site. Compared the inhibitory potency of analogues reported in this work with Brz, we found the potency of several YCZ analogues are greater than Brz, except 7d, 7e, 7f and $\mathbf{7 g}$. Nevertheless, among the compounds studied in this work, YCZ-14 is the most potent inhibitor on retardation stem elongation of Arabidopsis seedlings.

It is known that GA biosynthesis inhibitors, such as paclobutrazol, retard the stem elongation of many plant species by blocking ent-kaurene oxidation and also mildly affect other cytochrome P450 mono-oxygenases [25]. This retardation can be rescued by the application of GA. In order to rule out the GA biosynthesis inhibitor among these analogues, we tested the effects of brassinolide, the most biologically active BR, and GA on the recovery of chemical induced dwarfism of Arabidopsis 
seedlings grown in the dark. Accordingly, we selected analogues with $\mathrm{IC}_{50}$ values less than $1 \mu \mathrm{M}$ for studying the mode of actions. As shown in Table 2, compounds $7 \mathbf{a}$ to $7 \mathbf{d}$ and $\mathbf{7 g}$ were subjected to the bioassay at a concentration of $0.5 \mu \mathrm{M}$ and Arabidopsis seedlings were grown in the presence of $\mathrm{BL}$ $(10 \mathrm{nM})$ or GA $(1 \mu \mathrm{M})$ for 5 days in the dark. Data were expressed in percentage by the comparison of none chemical treated control.

Table 2. Retardation of Arabidopsis seedling growth by triazole derivatives and rescue of growth by $\mathrm{BL}$ and GA.

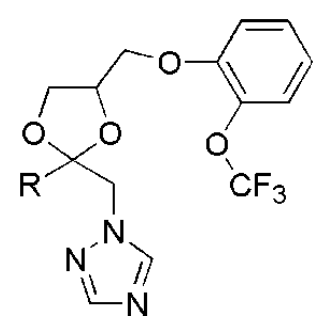

\begin{tabular}{|c|c|c|c|c|}
\hline \multirow{2}{*}{ No. } & \multirow{2}{*}{$-\mathbf{R}$} & \multicolumn{3}{|c|}{$\begin{array}{c}\text { Hypocotyl length, } \% \text { relative to untreated } \\
\text { Arabidopsis seedlings }(\%)\end{array}$} \\
\hline & & Chem *. & $\begin{array}{c}\text { Chem. + BL } \\
(10 \mathrm{nM})\end{array}$ & $\begin{array}{c}\text { Chem. + GA } \\
(1 \mu M)\end{array}$ \\
\hline Control & & 100 & $114.3 \pm 8.0$ & $104.3 \pm 5.4$ \\
\hline $7 a$ & & $45.9 \pm 2.5$ & $99.8 \pm 4.4$ & $48.0 \pm 3.7$ \\
\hline $7 b$ & & $37.6 \pm 3.2$ & $95.4 \pm 4.9$ & $43.8 \pm 3.7$ \\
\hline $7 c$ & & $32.5 \pm 3.2$ & $101.2 \pm 4.5$ & $39.7 \pm 2.5$ \\
\hline $7 d$ & & $56.7 \pm 1.1$ & $103.3 \pm 4.5$ & $51.8 \pm 2.8$ \\
\hline $7 \mathrm{~g}$ & & $21.2 \pm 2.3$ & $104.1 \pm 3.3$ & $31.5 \pm 3.7$ \\
\hline YCZ-14 & & $18.2 \pm 2.0$ & $97.0 \pm 3.9$ & $25.5 \pm 3.0$ \\
\hline Brz & & $56.0 \pm 3.3$ & $63.0 \pm 6.1$ & $61.8 \pm 2.3$ \\
\hline
\end{tabular}

* Data obtained from 20 seedlings grown in the dark. Chem. was assigned to be at a final concentration of $0.5 \mu \mathrm{M}$. All the experiments were done at least three times to establish the repeatability.

As shown by the data, in the presence of BL $(10 \mathrm{nM})$ or GA $(1 \mu \mathrm{M})$, the average hypocotyls length of Arabidopsis seedlings were approximately $114.3 \pm 8.0$ and $104.3 \pm 5.4 \%$, respectively. This result indicates that BL and GA stimulate hypocotyls elongation of Arabidopsis seedlings. We found all the test compounds exhibited high inhibitory activity on Arabidopsis seedlings elongation. The hypocotyls length Arabidopsis seedlings treated with $\mathbf{7 a}$ to $\mathbf{7 d}$ and $\mathbf{7 g}$ are approximately $45.9 \pm 2.5,37.6 \pm 3.2$, $32.5 \pm 3.2,56.7 \pm 1.1$ and $21.2 \pm 2.3 \%$ of non-chemically treated seedlings, respectively, while the positive control of YCZ-14 was approximately $18.2 \pm 2.0 \%$, and that of Brz was $56.0 \pm 3.3 \%$, 
respectively. This result indicate that at a concentration of $0.5 \mu \mathrm{M}$ of chemicals, YCZ-14 and $7 \mathrm{~g}$ strongly inhibited hypocotyls elongation of Arabidopsis seedlings, while Brz inhibited hypocotyls elongation at a degree about 56\%. This result clearly indicates that the potency of YCZ-14 and $\mathbf{7 g}$ are greater than that of Brz on inhibition hypocotyls elongation in Arabidopsis seedlings. Co-application of BL (10 nM) showed different recovery to different test compounds. Among the compounds listed in Table 2, all the YCZ analogues showed good recovery to BL, the hypocotyls length were $99.8 \pm 4.4$, $95.4 \pm 4.9,101.2 \pm 4.5,103.3 \pm 4.5$ and $104.1 \pm 3.3 \%$ of none chemical treated control, respectively, while the recovery degree of Brz is $63.0 \pm 6.1 \%$. Co-application of GA $(1 \mu \mathrm{M})$ did not show significant recovery for $\mathbf{Y C Z}$ analogues (from 31 to 51\%), while the recovery of Brz for GA treatment is $61.8 \pm 2.3 \%$. Interestingly, YCZ-14 not only inhibited hypocotyls elongation of Arabidopsis seedlings, it also induced morphological changes of Arabidopsis seedlings grown in the dark (As shown in Figure 2). These physiological changes can be counteracted by application of BL (Figure 2C) but not GA (Figure 2B).

Figure 2. Effect of YCZ-14 on 5 days old Arabidopsis seedlings grown in the dark. A: YCZ-14 $(0.5 \mu \mathrm{M})$; B: YCZ-14 $(0.5 \mu \mathrm{M})+\mathrm{GA}(1 \mu \mathrm{M})$; C: YCZ-14 $(0.5 \mu \mathrm{M})+\mathrm{BL}$ (10 nM); D: Control.

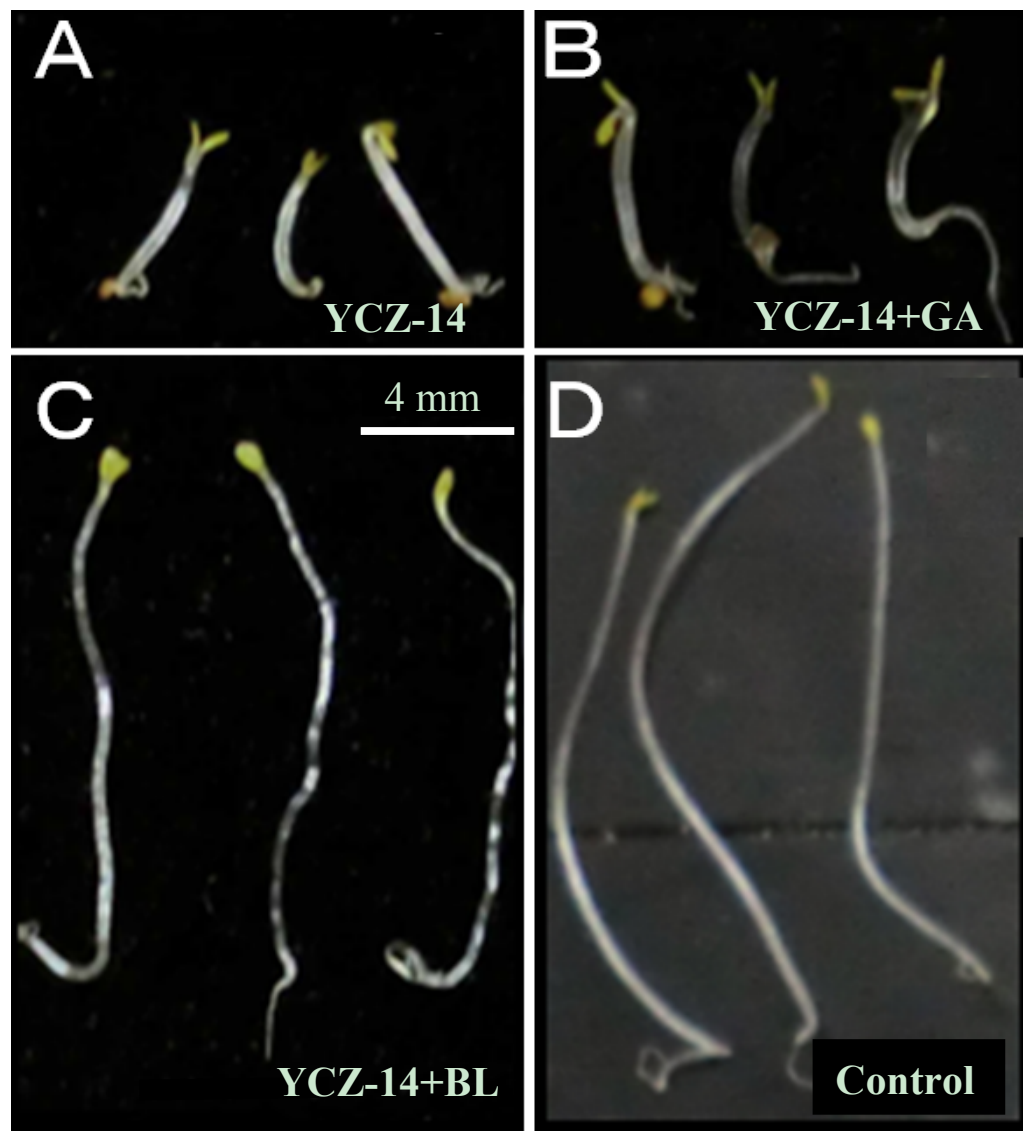

\section{Experimental}

\subsection{General}

Chemicals for synthesis were purchased from Kanto Chemicals Co. Ltd. (Tokyo, Japan) and Tokyo Kasei Co. Ltd. (Tokyo, Japan). Reagents are of the highest grade commercially available. Melting 
points (mp) were determined with a Yanako melting point apparatus (Tokyo, Japan). ${ }^{1} \mathrm{H}-\mathrm{NMR}$ spectra were recorded with a JEOL ECP-400 spectrometer (Tokyo, Japan), chemical shifts being expressed in ppm downfield from TMS as an internal standard. High resolution electrospray ionization Fourier transform ion cyclotron resonance mass spectra (ESI-FTICR) were recorded on an Exactive MS System (Thermo Fisher Scientific, Waltham, MA, USA).

\subsection{Synthesis}

Preparation of 1-phenyl-2-(1,2,4-triazol-1-yl)ethanone (2a). Compound 2a was prepared using phenacyl bromide as the starting material, as described previously [23]. To a vigorously stirred suspension of $1 H-1,2,4$-triazole $(5.52 \mathrm{~g}, 0.08 \mathrm{~mol})$ and phenacyl bromide 1a $(9.95 \mathrm{~g}, 0.05 \mathrm{~mol})$ in $30 \mathrm{~mL}$ acetone, was added triethylamine $(8.1 \mathrm{~g}, 0.05 \mathrm{~mol})$ dropwise over a period of $1 \mathrm{~h}$ with the temperature kept below $0{ }^{\circ} \mathrm{C}$, and the reaction mixture was stirred for another $30 \mathrm{~min}$ at room temperature. The mixture was filtered to remove triethylamine hydrobromide salt precipitates, the precipitates was washed with $3 \times 10 \mathrm{~mL}$ acetone, the combined washings and filtrate were evaporated under reduced pressure, and the residues were dissolved in $50 \mathrm{~mL}$ chloroform and then washed with $2 \times 25 \mathrm{~mL}$ water. After evaporation of chloroform, the yellow solid was recrystallized with 2-propanol, and 1-phenyl-2-(1,2,4-triazol-1-yl) ethanone (2a) was obtained as a white solid with a yield of 22.7\%. ${ }^{1} \mathrm{H}-\mathrm{NMR}\left(\mathrm{CDCl}_{3}\right), \delta: 5.69$ (s, 2H), 7.55 (t, $\left.J=7.8 \mathrm{~Hz}, 2 \mathrm{H}\right), 7.68(\mathrm{t}, J=7.5 \mathrm{~Hz}, 1 \mathrm{H}), 8.00$ (d, $J=7.8 \mathrm{~Hz}$, $2 \mathrm{H}), 8.03(\mathrm{~s}, 1 \mathrm{H}), 8.26(\mathrm{~s}, 1 \mathrm{H})$. Other compounds $\mathbf{2} \mathbf{b}-\mathbf{h}$ were prepared in a similar way by the reaction of triazole with the corresponding phenacyl bromide.

1-(4-Methylphenyl)-2-(1,2,4-triazol-1-yl)ethanone (2b). Yield: 61.0\%. ${ }^{1} \mathrm{H}-\mathrm{NMR}\left(\mathrm{CDCl}_{3}\right), \delta: 2.46$ (s, 3H), $5.66(\mathrm{~s}, 2 \mathrm{H}), 7.34(\mathrm{~d}, J=8.1 \mathrm{~Hz}, 2 \mathrm{H}), 7.89(\mathrm{~d}, J=8.1 \mathrm{~Hz}, 2 \mathrm{H}), 8.02(\mathrm{~s}, 1 \mathrm{H}), 8.25(\mathrm{~s}, 1 \mathrm{H})$.

1-(4-Fluorophenyl)-2-(1,2,4-triazol-1-yl)ethanone (2c). Yield: $50.6 \%$. ${ }^{1} \mathrm{H}-\mathrm{NMR}\left(\mathrm{CDCl}_{3}\right), \delta: 5.66$ (s, 2H), 7.21 7.25 (m, 2H), $8.02(\mathrm{~s}, 1 \mathrm{H}), 8.03 \sim 8.07$ (m, 2H), 8.25 (s, 1H).

1-(4-Trifluoromethylphenyl)-2-(1,2,4-triazol-1-yl)ethanone (2d). Yield: 19.8\%. ${ }^{1} \mathrm{H}-\mathrm{NMR}\left(\mathrm{CDCl}_{3}\right)$, $\delta: 5.71(\mathrm{~s}, 1 \mathrm{H}), 7.83(\mathrm{~d}, J=8.1 \mathrm{~Hz}, 2 \mathrm{H}), 8.04(\mathrm{~s}, 1 \mathrm{H}), 8.12(\mathrm{~d}, J=8.8 \mathrm{~Hz}, 2 \mathrm{H}), 8.26(\mathrm{~s}, 1 \mathrm{H})$.

1-Biphenyl-4-yl-2-(1,2,4-triazol-1-yl)ethanone (2e). Yield: 48.7\%. ${ }^{1} \mathrm{H}-\mathrm{NMR}\left(\mathrm{CDCl}_{3}\right), \delta: 5.67(\mathrm{~s}, 2 \mathrm{H})$, 7.37 7.59 (m, 3H), $7.70(\mathrm{~d}, J=8.1 \mathrm{~Hz}, 2 \mathrm{H}), 7.70$ (d, $J=8.1 \mathrm{~Hz}, 2 \mathrm{H}), 8.01$ (d, $J=4.0 \mathrm{~Hz}, 2 \mathrm{H}), 8.02$ (s, 1H), 8.32 (s, 1H).

1-Naphthalen-2-yl-2-(1,2,4-triazol-1-yl)ethanone (2f). Yield: 52.1\%. ${ }^{1} \mathrm{H}-\mathrm{NMR}\left(\mathrm{CDCl}_{3}\right), \quad \delta: 5.84$ (s, 2H), 7.60 7.70 (m, 2H), 7.91 8.03 (m, 5H), $8.32(\mathrm{~s}, 1 \mathrm{H}), 8.52(\mathrm{~s}, 1 \mathrm{H})$.

1-(2,4-Dichlorophenyl)-2-(1,2,4-triazol-1-yl)ethanone (2g). Yield: 52.6\%. ${ }^{1} \mathrm{H}-\mathrm{NMR}\left(\mathrm{CDCl}_{3}\right), \delta: 5.33$ (s, 2H), $6.92(\mathrm{~s}, 1 \mathrm{H}), 7.02(\mathrm{~s}, 1 \mathrm{H}), 7.38(\mathrm{~d}, J=9.1 \mathrm{~Hz}, 1 \mathrm{H}), 7.51(\mathrm{~s}, 2 \mathrm{H}), 7.57$ (d, $J=9.1 \mathrm{~Hz}, 1 \mathrm{H})$.

1-(3,4-Dichlorophenyl)-2-(1,2,4-triazol-1-yl)ethanone (2h). Yield: 65.2\%. ${ }^{1} \mathrm{H}-\mathrm{NMR}\left(\mathrm{CDCl}_{3}\right), \delta: 5.65$ $(\mathrm{s}, 2 \mathrm{H}), 7.65(\mathrm{~d}, J=8.4 \mathrm{~Hz}, 1 \mathrm{H}), 7.83\left(\mathrm{dd}, J_{1}=2.2 \mathrm{~Hz}, J_{2}=8.4 \mathrm{~Hz}, 1 \mathrm{H}\right), 8.03 \sim 8.09(\mathrm{~m}, 1 \mathrm{H}), 8.21$ $(\mathrm{s}, 1 \mathrm{H}), 8.25(\mathrm{~s}, 1 \mathrm{H})$. 
Preparation of 2,2-dimethyl-4-(4-methylbenzenesulfonate)-1,3-dioxolane-4-methanol (4). A dry $50 \mathrm{~mL}$ round-bottomed flask was charged with $p$-toluenesulfonyl chloride $(7.1 \mathrm{~g}, 37 \mathrm{mmol})$, to which pyridine $(15 \mathrm{~mL})$ was added while stirring under nitrogen with a magnetic stir bar. The reaction flask was placed inside a container; an ice/water mixture could be added in the event that the reaction becomes too exothermic. 2,2-Dimethyl-1,3-dioxolane-4-methanol (3.29 g, $25 \mathrm{mmol})$ was added slowly and stirred for $1.5 \mathrm{~h}$. The mixture was slowly added to a vigorously stirred mixture of de-ionized water $(70 \mathrm{~mL})$ and crushed ice $(70 \mathrm{~g})$ in a $300 \mathrm{~mL}$ Erlenmeyer flask and allowed to stir for an additional $0.5 \mathrm{~h}$. The white precipitate was collected on filter paper and washed with cold water $\left(\mathrm{H}_{2} \mathrm{O}\right)$. The product was dried under high vacuum and/or anhydrous sodium sulfate to obtain target compound 4 (4.15 g, 58.0\% yield). ${ }^{1} \mathrm{H}-\mathrm{NMR}\left(\mathrm{CDCl}_{3}\right), \delta: 1.32(\mathrm{~s}, 3 \mathrm{H}), 1.34(\mathrm{~s}, 3 \mathrm{H}), 2.46(\mathrm{~s}, 3 \mathrm{H}), 3.77(\mathrm{dd}, J=4.9,9.0 \mathrm{~Hz}, 1 \mathrm{H})$, $3.95-4.06(\mathrm{~m}, 3 \mathrm{H}), 4.25-4.31(\mathrm{~m}, 1 \mathrm{H}), 7.35(\mathrm{~d}, J=8.1 \mathrm{~Hz}, 2 \mathrm{H}), 7.80(\mathrm{~d}, J=8.4 \mathrm{~Hz}, 2 \mathrm{H})$.

Preparation of 1-tosyloxy-2, 3-propanediol (5). Compound 4 (8.21 g, $30 \mathrm{mmol})$ was dissolved in methanol $(300 \mathrm{~mL})$. Then, $0.5 \mathrm{~N}$ hydrochloric acid $(30 \mathrm{~mL})$ was added, and the resulting mixture was heated to reflux. Acetone and methanol were slowly distilled off. Additional methanol $(50 \mathrm{~mL})$ and $0.5 \mathrm{~N}$ hydrochloric acid $(20 \mathrm{~mL})$ was added, and the mixture was kept at room temperature until ketal hydrolysis was completed. The mixture was diluted with saturated sodium bicarbonate solution and extracted with EtOAc $(3 \times 80 \mathrm{~mL})$. The EtOAc extracts were combined, washed with brine $(20 \mathrm{~mL})$, dried over anhydrous sodium sulfate, filtered, concentrated, and purified by flash chromatography on silica gel $($ EtOAc/hexanes $=7: 3)$, affording target compound 5 (4.57 g, 64.8\% yield). ${ }^{1} \mathrm{H}-\mathrm{NMR}\left(\mathrm{CDCl}_{3}\right)$, $\delta: 2.46(\mathrm{~s}, 3 \mathrm{H}), 3.63(\mathrm{dd}, J=5.1,11.4 \mathrm{~Hz}, 1 \mathrm{H}), 3.71(\mathrm{dd}, J=4.2,11.5 \mathrm{~Hz}, 1 \mathrm{H}), 3.92-3.99(\mathrm{~m}, 1 \mathrm{H})$, $4.06-4.13(\mathrm{~m}, 2 \mathrm{H}), 7.37(\mathrm{~d}, J=6.6 \mathrm{~Hz}, 2 \mathrm{H})$, and $7.81(\mathrm{~d}, J=6.6 \mathrm{~Hz}, 2 \mathrm{H})$.

Preparation of 2RS,4RS-toluene-4-sulfonic acid 2-phenyl-2-1,2,4-triazol-1-ylmethyl-1,3-dioxolan-4ylmethyl ester (6a). Trifluoromethanesulfonic acid $(1.5 \mathrm{~mL}, 16 \mathrm{mmol})$ was added to a solution of 1-tosyloxy-2, 3-propanediol (5, $1 \mathrm{~g}, 4.0 \mathrm{mmol})$ and ketone $\mathbf{2 a}(1 \mathrm{~g}, 3.9 \mathrm{mmol})$ in toluene $(10 \mathrm{~mL})$ under nitrogen. Then, the reaction mixture was stirred at room temperature for $60 \mathrm{~h}$. The reaction was quenched by adding saturated sodium bicarbonate solution $(25 \mathrm{~mL})$, extracted with EtOAc $(3 \times 30 \mathrm{~mL})$, washed with brine, and dried over anhydrous sodium sulfate. The solvent was removed, and the residue was re-dissolved in $2 \mathrm{~mL}$ EtOAc. $p$-Toluensulfonic acid monohydrate $(750 \mathrm{mg}, 3.9 \mathrm{mmol}) \mathrm{in}$ EtOAc $(2 \mathrm{~mL})$ was added dropwise to preferentially precipitate 6 as a white solid. The mixture was stirred for $30 \mathrm{~min}$ and filtered to obtain target compound salt $\mathbf{6}$, which was recrystallized from acetonitrile (49.5\% yield). ${ }^{1} \mathrm{H}-\mathrm{NMR}\left(\mathrm{CD}_{3} \mathrm{OD}\right), \delta: 2.36(\mathrm{~s}, 3 \mathrm{H}), 2.46(\mathrm{~s}, 3 \mathrm{H}), 3.62(\mathrm{dd}, J=5.1,8.4 \mathrm{~Hz}$, $1 \mathrm{H}), 3.73-3.80(\mathrm{~m}, 2 \mathrm{H}), 3.94-3.97(\mathrm{~m}, 1 \mathrm{H}), 4.20-4.22(\mathrm{~m}, 1 \mathrm{H}), 4.77(\mathrm{~s}, 2 \mathrm{H}), 7.22-7.24(\mathrm{~m}, 2 \mathrm{H})$, 7.41-7.51 (m, 6H), 7.69-7.71 (m, 2H), 7.76-7.78 (m, 2H), $8.50(\mathrm{~s}, 1 \mathrm{H})$, and 9.29 (s, 1H).

Other compounds $\mathbf{6 b}-\mathbf{h}$ were prepared in a similar way by the reaction of $\mathbf{5}$ with the corresponding ketone 2.

2RS,4RS-Toluene-4-sulfonic acid 2-(4methylphenyl)-2-1,2,4-triazol-1-ylmethyl-1,3-dioxolan-4-ylmethyl ester (6b). (23.1\%). ${ }^{1} \mathrm{H}-\mathrm{NMR}\left(\mathrm{CD}_{3} \mathrm{OD}\right), \delta: 2.35(\mathrm{~d}, J=7.3 \mathrm{~Hz}, 6 \mathrm{H}), 3.60(\mathrm{dd}, J=4.9,8.6 \mathrm{~Hz}$, $1 \mathrm{H}), 3.71-3.79(\mathrm{~m}, 2 \mathrm{H}), 3.92-3.95(\mathrm{~m}, 1 \mathrm{H}), 4.17-4.20(\mathrm{~m}, 1 \mathrm{H}), 4.73(\mathrm{~s}, 2 \mathrm{H}), 7.41$ (d, J=8.1 Hz, 2H), $7.46(\mathrm{~d}, J=8.4 \mathrm{~Hz}, 2 \mathrm{H}), 7.70(\mathrm{~d}, J=8.4 \mathrm{~Hz}, 2 \mathrm{H}), 7.76(\mathrm{~d}, J=8.1 \mathrm{~Hz}, 2 \mathrm{H}), 8.66(\mathrm{~s}, 1 \mathrm{H}), 9.53(\mathrm{~d}, 1 \mathrm{H})$. 
2RS,4RS-Toluene-4-sulfonic acid 2-(4-fluorophenyl)-2-1,2,4-triazol-1-ylmethyl-1,3-dioxolan-4-ylmethyl ester (6c). (36.5\%). ${ }^{1} \mathrm{H}-\mathrm{NMR}\left(\mathrm{CDCl}_{3}\right), \delta: 2.47$ (s, 3H), 3.49-3.53 (m, 1H), $3.69(\mathrm{dd}, J=4.4,8.8 \mathrm{~Hz}$, $1 \mathrm{H}), 3.77-3.83(\mathrm{~m}, 2 \mathrm{H}), 4.21-4.27(\mathrm{~m}, 1 \mathrm{H}), 4.45(\mathrm{~s}, 2 \mathrm{H}), 7.02-7.08(\mathrm{~m}, 2 \mathrm{H}), 7.37-7.41(\mathrm{~m}, 4 \mathrm{H})$, 7.77-7.81 (m, 3H), $8.10(\mathrm{~s}, 1 \mathrm{H})$.

2RS,4RS-Toluene-4-sulfonic acid 2-(4-trifluoromethylphenyl)-2-1,2,4-triazol-1-yl-methyl-1,3-dioxolan-4-yl-methyl ester (6d). (36.1\%). ${ }^{1} \mathrm{H}-\mathrm{NMR}\left(\mathrm{CDCl}_{3}\right), \delta: 2.48(\mathrm{~s}, 3 \mathrm{H}), 3.55$ (dd, $J=5.6,10.6 \mathrm{~Hz}$, $1 \mathrm{H}), 3.78-3.85(\mathrm{~m}, 3 \mathrm{H}), 4.22-4.28(\mathrm{~m}, 1 \mathrm{H}), 4.48(\mathrm{~s}, 2 \mathrm{H}), 7.36-7.41(\mathrm{~m}, 2 \mathrm{H}), 7.54-7.69(\mathrm{~m}, 4 \mathrm{H})$, $7.78-7.82(\mathrm{~m}, 3 \mathrm{H}), 8.11(\mathrm{~s}, 1 \mathrm{H})$.

2RS,4RS-Toluene-4-sulfonic acid 2-(biphenyl-4-yl)-2-1,2,4-triazol-1-yl-methyl-1,3-dioxolan-4-ylmethyl ester (6e). (42.7\%). ${ }^{1} \mathrm{H}-\mathrm{NMR}\left(\mathrm{CDCl}_{3}\right), \delta: 2.48(\mathrm{~s}, 3 \mathrm{H}), 3.48(\mathrm{dd}, J=6.2,10.3 \mathrm{~Hz}, 1 \mathrm{H}), 3.69$ $(\mathrm{dd}, J=4.4,8.8 \mathrm{~Hz}, 1 \mathrm{H}), 3.79-3.86(\mathrm{~m}, 2 \mathrm{H}), 4.27-4.30(\mathrm{~m}, 1 \mathrm{H}), 4.50(\mathrm{~d}, J=1.5 \mathrm{~Hz}, 2 \mathrm{H}), 7.37-7.41$ $(\mathrm{m}, 3 \mathrm{H}), 7.43-7.50(\mathrm{~m}, 4 \mathrm{H}), 7.57-7.60(\mathrm{~m}, 4 \mathrm{H}), 7.79(\mathrm{~d}, J=8.4 \mathrm{~Hz}, 2 \mathrm{H}), 7.83(\mathrm{~s}, 1 \mathrm{H}), 8.10(\mathrm{~s}, 1 \mathrm{H})$.

2RS,4RS-Toluene-4-sulfonic acid 2-(naphthalen-2-yl)-2-1,2,4-triazol-1-yl-methyl-1,3-dioxolan-4-ylmethyl ester (6f). (26.3\%). ${ }^{1} \mathrm{H}-\mathrm{NMR}\left(\mathrm{CDCl}_{3}\right), \delta: 2.48(\mathrm{~s}, 3 \mathrm{H}), 3.53(\mathrm{dd}, J=6.2,10.6 \mathrm{~Hz}, 1 \mathrm{H})$, $3.61-3.65(\mathrm{~m}, 1 \mathrm{H}), 3.81-3.86(\mathrm{~m}, 2 \mathrm{H}), 4.28-4.30(\mathrm{~m}, 1 \mathrm{H}), 4.56(\mathrm{~d}, J=2.2 \mathrm{~Hz}, 2 \mathrm{H}), 7.39$ (dd, $J=8.1,11.7 \mathrm{~Hz}, 3 \mathrm{H}), 7.49-7.56(\mathrm{~m}, 2 \mathrm{H}), 7.79-7.95(\mathrm{~m}, 7 \mathrm{H}), 8.13(\mathrm{~s}, 1 \mathrm{H})$.

2RS,4RS-Toluene-4-sulfonic acid 2-(2,4-dichlorophyenyl)-2-1,2,4-triazol-1-yl-methyl-1,3-dioxolan-4$y$ l-methyl ester (6g) (14.0\%). ${ }^{1} \mathrm{H}-\mathrm{NMR}\left(\mathrm{CDCl}_{3}\right), \delta: 2.47(\mathrm{~s}, 3 \mathrm{H}), 3.51(\mathrm{dd}, J=6.4,10.4 \mathrm{~Hz}, 1 \mathrm{H}), 3.71$ $(\mathrm{dd}, J=4.3,9.3 \mathrm{~Hz}, 1 \mathrm{H}), 3.80-3.85(\mathrm{~m}, 2 \mathrm{H}), 4.25-4.28(\mathrm{~m}, 1 \mathrm{H}), 4.67-4.79(\mathrm{~m}, 2 \mathrm{H}), 7.38-7.47$ $(\mathrm{m}, 4 \mathrm{H}), 7.77-7.81(\mathrm{~m}, 4 \mathrm{H}), 8.11(\mathrm{~s}, 1 \mathrm{H})$.

2RS,4RS-Toluene-4-sulfonic acid 2-(3,4-dichlorophyenyl)-2-1,2,4-triazol-1-yl-methyl-1,3-dioxolan-4$y$ l-methyl ester (6h). (45.8\%). ${ }^{1} \mathrm{H}-\mathrm{NMR}\left(\mathrm{CD}_{3} \mathrm{OD}\right), \delta: 2.46(\mathrm{~s}, 3 \mathrm{H}), 3.64(\mathrm{dd}, J=5.1,8.8 \mathrm{~Hz}, 1 \mathrm{H})$, $3.76-3.81(\mathrm{~m}, 2 \mathrm{H}), 3.95-3.98(\mathrm{~m}, 1 \mathrm{H}), 4.22-4.24(\mathrm{~m}, 1 \mathrm{H}), 4.79(\mathrm{~s}, 2 \mathrm{H}), 7.23(\mathrm{~d}, J=8.1 \mathrm{~Hz}, 2 \mathrm{H})$, 7.44-7.48 (m, 3H), 7.77 (d, $J=8.4 \mathrm{~Hz}, 2 \mathrm{H}), 8.62$ (s, 1H), 9.48 (s, 1H).

Preparation of 1-[2-Phenyl-4-(2-trifluoromethoxyphenoxymethyl)-1,3-dioxolan-2-yl-methyl]-1H-1,2,4triazole (7a). Potassium hydroxide (160 mg, $2.8 \mathrm{mmol}$ ) was added to a solution of tosylate 6 (485 $\mathrm{mg}$, $0.78 \mathrm{mmol})$ and 2-trifluoromethoxyphenol $(133 \mathrm{mg}, 0.72 \mathrm{mmol})$ in dry DMF $(5 \mathrm{~mL})$, and the reaction mixture was heated at $50{ }^{\circ} \mathrm{C}$ overnight. After cooling to room temperature, the reaction mixture was diluted with water $(20 \mathrm{~mL})$ and EtOAc $(20 \mathrm{~mL})$, and the organic phase was separated. The aqueous phase was extracted with EtOAc $(3 \times 20 \mathrm{~mL})$. All of the organic layers were combined, washed with brine $(20 \mathrm{~mL})$, dried over anhydrous sodium sulfate, filtered, concentrated, and purified by flash chromatography on silica gel (EtOAc/hexanes $=1: 1$ ), affording target compound 7a (58.9\% yield), mp: $100-103{ }^{\circ} \mathrm{C} .{ }^{1} \mathrm{H}-\mathrm{NMR}\left(\mathrm{CD}_{3} \mathrm{OD}\right), \delta: 3.34-3.38(\mathrm{~m}, 1 \mathrm{H}), 3.86-3.95(\mathrm{~m}, 3 \mathrm{H}), 4.40-4.44(\mathrm{~m}, 1 \mathrm{H})$, 4.51-4.60 (m, 2H), 6.87-6.89 (m, 1H), 6.95-7.00 (m, 1H), 7.21-7.28 (m, 2H), 7.40-7.44 (m, 3H), 7.51-7.54 (m, 2H), $7.93(\mathrm{~s}, 1 \mathrm{H}), 8.17(\mathrm{~s}, 1 \mathrm{H})$. HRMS-ESI calculated for $\mathrm{C}_{19} \mathrm{H}_{19} \mathrm{~N}_{3} \mathrm{O}_{3} \mathrm{Na}[\mathrm{M}+\mathrm{Na}]^{+}$was 394.0928, and 394.0891 was the experimental value. 
Other compounds $\mathbf{7 b}-\mathbf{h}$ were prepared in a similar method, by reacting 2-trifluoromethoxyphenol with the corresponding 6 .

1-[2-p-Tolyl-4-(2-trifluoromethoxyphenoxymethyl)-1,3-dioxolan-2-ylmethyl]-1H-1,2,4-triazole (7b). (69.6\%). mp: $79.8-81.3{ }^{\circ} \mathrm{C} .{ }^{1} \mathrm{H}-\mathrm{NMR}\left(\mathrm{CDCl}_{3}\right)$; $\delta: 2.37(\mathrm{~s}, 3 \mathrm{H}), 3.33-3.37(\mathrm{~m}, 1 \mathrm{H}), 3.84-3.94(\mathrm{~m}, 3 \mathrm{H})$, 4.37-4.43 (m, 1H), 4,49-4.57 (m, 2H), 6.86-6.89 (m, 1H), 6.95-6.99 (m, 1H), 7.20-7.28 (m, 4H), $7.38-7.41(\mathrm{~m}, 2 \mathrm{H}), 7.93(\mathrm{~s}, 1 \mathrm{H}), 8.16(\mathrm{~s}, 1 \mathrm{H})$. HRMS-ESI $m / z$ calculated for $\mathrm{C}_{21} \mathrm{H}_{20} \mathrm{~F}_{3} \mathrm{~N}_{3} \mathrm{O}_{4} \mathrm{Na}$ $[\mathrm{M}+\mathrm{Na}]^{+} 458.1298$, found 458.1248 .

1-[2-(4-Fluorophenyl)-4-(2-trifluoromethoxyphenoxymethyl)-1,3-dioxolan-2-ylmethyl]-1H-1,2,4-triazole (7c). (31.6\%). mp: $60.8-62.5{ }^{\circ} \mathrm{C} .{ }^{1} \mathrm{H}-\mathrm{NMR}\left(\mathrm{CDCl}_{3}\right), \delta: 3.40(\mathrm{dd}, J=7.1,9.3 \mathrm{~Hz}, 1 \mathrm{H}), 3.86-3.94$ (m, $3 \mathrm{H}), 4.39-4.43(\mathrm{~m}, 1 \mathrm{H}), 4.53(\mathrm{~d}, J=5.1 \mathrm{~Hz}, 2 \mathrm{H}), 6.87-6.89(\mathrm{~m}, 1 \mathrm{H}), 6.96-7.05(\mathrm{~m}, 1 \mathrm{H}), 7.06-7.10$ $(\mathrm{m}, 2 \mathrm{H}), 7.21-7.28(\mathrm{~m}, 2 \mathrm{H}), 7.46-7.50(\mathrm{~m}, 2 \mathrm{H}), 7.91(\mathrm{~s}, 1 \mathrm{H}), 8.16(\mathrm{~s}, 1 \mathrm{H})$. HRMS-ESI $\mathrm{m} / z$ calculated for $\mathrm{C}_{20} \mathrm{H}_{17} \mathrm{~F}_{4} \mathrm{~N}_{3} \mathrm{O}_{4} \mathrm{Na}[\mathrm{M}+\mathrm{Na}]^{+} 462.1047$, found 462.0999 .

1-[2-(4-Trifluoromethylphenyl)-4-(2-trifluoromethoxyphenoxymethyl)-1,3-dioxolan-2-ylmethyl]-1H1,2,4-triazole (7d). (28.2\%). mp: 93.1-94.5 ${ }^{\circ} \mathrm{C} .{ }^{1} \mathrm{H}-\mathrm{NMR}\left(\mathrm{CDCl}_{3}\right), \delta: 3.43-3.48(\mathrm{~m}, 1 \mathrm{H}), 3.83-3.93$ (m, 3H), 4.41-4.45 (m, 1H), 4.51-4.60 (m, 2H), 6.88-6.90 (m, 1H), 6.97-7.02 (m, 1H), 7.22-7.29 (m, $2 \mathrm{H}), 7.63-7.68(\mathrm{~m}, 4 \mathrm{H}), 7.92(\mathrm{~s}, 1 \mathrm{H}), 8.19(\mathrm{~s}, 1 \mathrm{H})$. HRMS-ESI $m / z$ calculated for $\mathrm{C}_{21} \mathrm{H}_{17} \mathrm{~F}_{6} \mathrm{~N}_{3} \mathrm{O}_{4} \mathrm{Na}$ $[\mathrm{M}+\mathrm{Na}]^{+}$512.1015, found 512.0963 .

1-[2-Biphenyl-4-yl-4-(2-trifluoromethoxyphenoxymethyl)-1,3-dioxolan-2-ylmethyl]-1H-1,2,4-triazole (7e). (30.6\%). mp: 116.6-117.8 ${ }^{\circ} \mathrm{C} .{ }^{1} \mathrm{H}-\mathrm{NMR}\left(\mathrm{CDCl}_{3}\right), \delta: 3.35-3.40(\mathrm{~m}, 1 \mathrm{H}), 3.87-3.91(\mathrm{~m}, 2 \mathrm{H})$, 3.96-4.00 (m, 1H), 4.44-4.48 (m, 1H), 4.55-4.64 (m, 2H), 6.88-6.91 (m, 1H), 6.96-7.00 (m, 1H), 7.21-7.29 (m, 2H), 7.36-7.40 (m, 1H), 7.45-7.48 (m, 2H), 7.58-7.64 (m, 6H), $7.95(\mathrm{~s}, 1 \mathrm{H}), 8.21$ (s, 1H). HRMS-ESI $m / z$ calculated for $\mathrm{C}_{26} \mathrm{H}_{22} \mathrm{~F}_{3} \mathrm{~N}_{3} \mathrm{O}_{4} \mathrm{Na}[\mathrm{M}+\mathrm{Na}]^{+} 520.1454$, found 520.1404 .

1-Naphthalen-2-yl-4-(2-trifluoromethoxyphenoxymethyl)-1,3-dioxolan-2-ylmethyl]-1H-1,2,4-triazole (7f). (30.5\%). mp: 98.5-99.6 ${ }^{\circ} \mathrm{C} .{ }^{1} \mathrm{H}-\mathrm{NMR}\left(\mathrm{CDCl}_{3}\right), \delta: 3.39-3.43(\mathrm{~m}, 1 \mathrm{H}), 3.88-3.99(\mathrm{~m}, 3 \mathrm{H})$, $4.47-4.48(\mathrm{~m}, 1 \mathrm{H}), 4.59-4.68(\mathrm{~m}, 2 \mathrm{H}), 6.89-7.02(\mathrm{~m}, 2 \mathrm{H}), 7.21-7.28(\mathrm{~m}, 2 \mathrm{H}), 7.51-7.61(\mathrm{~m}, 3 \mathrm{H})$, 7.85-8.02 (m, 5H), $8.21(\mathrm{~s}, 1 \mathrm{H})$. HRMS-ESI $m / z$ calculated for $\mathrm{C}_{24} \mathrm{H}_{20} \mathrm{~F}_{3} \mathrm{~N}_{3} \mathrm{O}_{4} \mathrm{Na}[\mathrm{M}+\mathrm{Na}]^{+}$was 494.1298, and 494.1248 was found.

1-[2-(2,4-Dichlorophenyl)-4-(2-trifluoromethoxyphenoxymethyl)-1,3-dioxolan-2-ylmethyl]-1H-1,2,4triazole (7g). (43.6\%). ${ }^{1} \mathrm{H}-\mathrm{NMR}\left(\mathrm{CDCl}_{3}\right), \delta: 3.42-3.46(\mathrm{~m}, 1 \mathrm{H}), 3.82-3.98(\mathrm{~m}, 3 \mathrm{H}), 4.40-4.46(\mathrm{~m}$, $1 \mathrm{H}), 4.75-4.88(\mathrm{~m}, 2 \mathrm{H}), 6.88-6.90(\mathrm{~m}, 1 \mathrm{H}), 6.96-7.02(\mathrm{~m}, 1 \mathrm{H}), 7.22-7.29(\mathrm{~m}, 3 \mathrm{H}), 7.47-7.55(\mathrm{~m}$, $2 \mathrm{H}), 7.90(\mathrm{~s}, 1 \mathrm{H}), 8.19$ (s, 1H). HRMS-ESI $m / z$ calculated for $\mathrm{C}_{20} \mathrm{H}_{16} \mathrm{Cl}_{2} \mathrm{~F}_{3} \mathrm{~N}_{3} \mathrm{O}_{4} \mathrm{Na}[\mathrm{M}+\mathrm{Na}]^{+}$512.0362, found 512.0310 .

1-[2-(3,4-Dichlorophenyl)-4-(2-trifluoromethoxyphenoxymethyl)-1,3-dioxolan-2-ylmethyl]-1H-1,2,4triazole (7h). (42.7\%) mp: 81.5-82.3 ${ }^{\circ} \mathrm{C} .{ }^{1} \mathrm{H}-\mathrm{NMR}\left(\mathrm{CDCl}_{3}\right), \delta: 3.43-3.47(\mathrm{~m}, 1 \mathrm{H}), 3.86-3.96(\mathrm{~m}, 3 \mathrm{H})$, $4.40-4.46(\mathrm{~m}, 1 \mathrm{H}), 4.48-4.57(\mathrm{~m}, 2 \mathrm{H}), 6.87-6.90(\mathrm{~m}, 1 \mathrm{H}), 6.97-7.01(\mathrm{~m}, 1 \mathrm{H}), 7.22-7.33(\mathrm{~m}, 3 \mathrm{H})$, 7.46-7.48 (m, 1H), 7.60-7.61 (m, 1H), $7.92(\mathrm{~s}, 1 \mathrm{H}), 8.18(\mathrm{~s}, 1 \mathrm{H})$. HRMS-ESI $\mathrm{m} / \mathrm{z}$ calculated for $\mathrm{C}_{20} \mathrm{H}_{16} \mathrm{Cl}_{2} \mathrm{~F}_{3} \mathrm{~N}_{3} \mathrm{O}_{4} \mathrm{Na}[\mathrm{M}+\mathrm{Na}]^{+}$512.0362, found 512.0311 . 


\subsection{Bioassay Methods for Evaluation Brassinosteroid Biosynthesis Inhibitor}

Seeds of Arabidopsis (Columbia ecotype) were purchased from Lehle Seeds (Round Rock, TX, USA). The seeds used for the assay were sterilized in $1 \% \mathrm{NaOCl}$ for $20 \mathrm{~min}$ and washed with sterile distilled water. Seeds were sown on a $1 \%$ solidified agar medium containing half Murashige and Skoog salt in Petri dishes with or without chemicals. Plants were grown in $16 \mathrm{~h}$ light $\left(240 \mu \mathrm{E} / \mathrm{m}^{2} \mathrm{~s}\right)$ and $8 \mathrm{~h}$ dark conditions at $22{ }^{\circ} \mathrm{C}$ in a growth chamber with or without added chemicals. For the dark condition, Petri dishes were wrapped in four layers of aluminum foil. The biological activities of the test compounds were measured 5 days after sowing the seeds. The hypocotyl length of 15-20 Arabidopsis seedlings was measured with a ruler, and each experiment was repeated at least two times.

\section{Conclusions}

We have reported the synthesis and structure-activity relationships studies of $2 R S, 4 R S$-1-[2-phenyl4-[2-(2-trifluromethoxyphenoxy)-ethyl]-1,3-dioxolan-2-yl-methyl]-1H-1,2,4-triazole derivatives as potent inhibitors of brassinosteroid biosynthesis. The analogues with different aromatic substituent at position 2 of dioxolane were successfully synthesized by a method we described previously [22]. The biological activity of the test compounds were evaluated by a method using Arabidopsis seedlings grown in the dark. We found that the variation of aromatic substituent significantly affect the inhibitory potency. Structure-activity relationships studies indicated that a 4-chlorophenyl analogue is the most potent inhibitor of BR biosynthesis, with an $\mathrm{IC}_{50}$ value approximately $0.12 \pm 0.04 \mu \mathrm{M}$, while a bulky biphenyl group exhibited a great negative effect on promoting the inhibitory potency with an $\mathrm{IC}_{50}$ larger than $10 \mu \mathrm{M}$.

\section{Acknowledgments}

This work was supported in whole or in part by Japan Science and Technology Agency Grant No. AS232Z01258E (to K. OH).

\section{References and Notes}

1. Clouse, S.D.; Sasse, J.M. Brassinosteroids: Essential regulators of plant growth and development. Annu. Rev. Plant Physiol. Plant Mol. Biol. 1998, 49, 427-451.

2. Sasse, J. Physiological actions of brassinosteroids: An update. J. Plant Growth Regul. 2003, 22, 276-288.

3. Krishna, P. Brassinosteroid-mediated stress responses. J. Plant Growth Regul. 2003, 22, 289-297.

4. Choe, S.; Dilkes, B.P.; Gregory, B.D.; Ross, A.S.; Yuan, H.; Noguchi, T.; Fujioka, S.; Takatsuto, S.; Tanaka, A.; Yoshida, S.; et al. The Arabidopsis dwarfl mutant is defective in the conversion of 24-methylenecholesterol to campesterol in brassinosteroid biosynthesis. Plant Physiol. 1999, 119, 897-907.

5. Bishop, G.J.; Nomura, T.; Yokota, T.; Harrison, K.; Noguchi, T.; Fujioka, S.; Takatsuto, S.; Jones, J.D.; Kamiya, Y. The tomato DWARF enzyme catalyses C-6 oxidation in brassinosteroid biosynthesis. Proc. Natl. Acad. Sci. USA 1999, 96, 1761-1766. 
6. Hong, Z.; Ueguchi-Tanaka, M.; Umemura, K.; Uozu, S.; Fujioka, S.; Takatsuto, S.; Yoshida, S.; Ashikari, M.; Kitano, H.; Matsuoka, M. A rice brassinosteroid-deficient mutant, ebisu dwarf (d2), is caused by a loss of function of a new member of cytochrome P450. Pant Cell 2003, 15, 2900-2910.

7. Nomura, T.; Nakayama, M.; Reid, J.B.; Takeuchi, Y.; Yokota, T. Blockage of Brassinosteroid Biosynthesis and Sensitivity Causes Dwarfism in Garden Pea. Plant Physiol. 1997, 113, 31-37.

8. Wu, C.Y.; Trieu, A.; Radhakrishnan, P.; Kwok, S.F.; Harris, S.; Zhang, K.; Wang, J.; Wan, J.; Zhai, H.; Takatsuto, S.; et al. Brassinosteroids regulate grain filling in rice. Plant Cell 2008, 20, 2130-2145.

9. Sakamoto, T.; Morinaka, Y.; Ohnishi, T.; Sunohara, H.; Fujioka, S.; Ueguchi-Tanaka, M.; Mizutani, M.; Sakata, K.; Takatsuto, S.; Yoshida, S.; et al. Erect leaves caused by brassinosteroid deficiency increase biomass production and grain yield in rice. Nat. Biotechnol. 2006, 24, 105-109.

10. Min, Y.K.; Asami, T.; Fujioka, S.; Murofushi, N.; Yamaguchi I.; Yoshida, S. New lead compounds for brassinosteroid biosynthesis inhibitors. Bioorg. Med. Chem. Lett. 1999, 9, 425-430.

11. Asami, T.; Min, Y.K.; Nagata, N.; Yamagishi, K.; Takatsuto, S.; Fujioka, S.; Murofushi, N.; Yamaguchi, I.; Yoshida, S. Characterization of brassinazole, a triazole-type brassinosteroid biosynthesis inhibitor. Plant Physiol. 2000, 123, 93-100.

12. Wang, Z.Y.; Nakano, T.; Gendron, J.; He, J.; Chen, M.; Vafeados, D.; Yang, Y.; Fujioka, S.; Yoshida, S.; Asami, T.; et al. Nuclear-localized BZR1 mediates brassinosteroid-induced growth and feedback suppression of brassinosteroid biosynthesis. Dev. Cell 2002, 4, 505-513.

13. Mathur, J.; Molnár, G.; Fujioka, S.; Takatsuto, S.; Sakurai, A.; Yokota, T.; Adam, G.; Voigt, B.; Nagy, F.; Maas, C.; et al. Transcription of the Arabidopsis CPD gene, encoding a steroidogenic cytochrome P450, is negatively controlled by brassinosteroids. Plant J. 1998, 14, 593-602.

14. Kim, T.W.; Chang, S.C.; Lee, J.S.; Hwang, B.; Takatsuto, S.; Yokota, T.; Kim, S.K. Cytochrome P450-catalyzed brassinosteroid pathway activation through synthesis of castasterone and brassinolide in Phaseolus vulgaris. Phytochemistry 2004, 65, 679-689.

15. Kim, T.W.; Hwang, J.Y.; Kim, Y.S.; Joo, S.H.; Chang, S.C.; Lee, J.S.; Takatsuto, S.; Kim, S.K. Arabidopsis CYP85A2, a cytochrome P450, mediates the Baeyer-Villiger oxidation of castasterone to brassinolide in brassinosteroid biosynthesis. Plant Cell 2005, 17, 2397-2412.

16. Testa, B.; Jenner, P. Inhibitors of Cytochrome P-450s and their mechanism of action. Drug Metab. Rev. 1981, 12, 1-117.

17. Rogerson, T.D.; Wilkinson, C.F.; Hetarski, K. Steric factors in the inhibitory interaction of imidazoles with microsomal enzymes. Biochem. Pharmacol. 1977, 26, 1039-1042.

18. Oh, K. Jasmonic acid biosynthesis inhibitor. Regul. Plant Growth Devel. 2009, 44, 166-169.

19. Oh, K.; Murofushi, N. Design and synthesis of novel imidazole derivatives as potent inhibitors of allene oxide synthase (CYP74). Bioorg. Med. Chem. 2002, 10, 3707-3711.

20. Oh, K.; Seki, Y.; Murofushi, N.; Yoshizawa, Y. Effect of miconazole, an antifungal agent, on allene oxide synthase: Inhibition, kinetics, and binding. Pestic. Biochem. Physiol. 2009, 94, 107-111.

21. Oh, K.; Asami, T.; Matsui, K.; Howe, G.A.; Murofushi, N. Characterization of novel imidazole derivative, JM-8686, a potent inhibitor of allene oxide synthase. FEBS Lett. 2006, 580, 5791-5796.

22. Oh, K.; Yamada, K.; Asami, T.; Yoshizawa, Y. Synthesis of novel brassinosteroid biosynthesis inhibitors based on the ketoconazole scaffold. Bioorg. Med. Chem. Lett. 2012, 22, 1625-1628. 
23. Oh, K.; Shimura, Y.; Ishikawa, K.; Ito, Y.; Asami, T.; Murofushi, N.; Yoshizawa, Y. Asymmetric synthesis and stereochemical structure-activity relationship of $(R)$ - and $(S)-8-[1-(2,4-$ dichlorophenyl)-2-imidazol-1-yl-ethoxy] octanoic acid heptyl ester, a potent inhibitor of allene oxide synthase. Bioorg. Med. Chem. 2008, 16, 1090-1095.

24. Sekimata, K.; Ohnishi, T.; Mizutani, M.; Todoroki, Y.; Han, S.Y.; Uzawa, J.; Fujioka, S.; Yoneyama, K.; Takeuchi, Y.; Takatsuto, S.; et al. Brz220 interacts with DWF4, a cytochrome P450 monooxygenase in brassinosteroid biosynthesis, and exerts biological activity. Biosci. Biotechnol. Biochem. 2008, 72, 7-12.

25. Sekimata, K.; Han, S.Y.; Yoneyama, K.; Takeuchi, Y.; Yoshida, S.; Asami, T. A specific and potent inhibitor of brassinosteroid biosynthesis possessing a dioxolane ring. J. Agric. Food Chem. 2002, 50, 3486-3490.

Sample Availability: Samples of the compounds are available from the authors.

(C) 2012 by the authors; licensee MDPI, Basel, Switzerland. This article is an open access article distributed under the terms and conditions of the Creative Commons Attribution license (http://creativecommons.org/licenses/by/3.0/). 